\title{
Kinerja Dan Motivasi Penyuluh Pertanian di Provinsi Jawa Barat
}

\section{Job Performance and Motivation of Agricultural Extension Agent in West Java Province}

\author{
Nani Sufiani Suhanda ${ }^{1 *}$, Amri Jahi ${ }^{2}$, Basita G. Sugihen ${ }^{2}$, dan Djoko Susanto ${ }^{3}$ \\ ${ }^{1}$ Staf Departemen Pertanian RI, Jakarta \\ ${ }^{2}$ Departemen Sains Komunikasi dan Pengembangan Masyarakat, \\ Fakultas Ekologi Manusia, Institut Pertanian Bogor \\ ${ }^{3}$ Pusat Penelitian Gizi Departemen Kesehatan
}

\begin{abstract}
A research to investigate the relationship of the agricultural extension agent (AEA) motivator-hygiene factors and their job performances at different agriculture extension institution in west java was conducted in August through Desember 2007. The objectives of this study were:1) to identify their job performance and 2) to determine the relationship of the agent motivator-hygiene factors and their job performances in west Java Province. A total of 260 AEA from 17 districts in West Java were selected by a stratified randomized sampling technique with proportional allocation as a sample of the study. Descriptive statistics were used to determine the agents' description on their motivator-hygiene factors, whereas the Kendall coefficient of concordance $W$ was used to analyze the relationship of AEA performance and their motivator-hygiene factors. The results shown that some substantial works need to be done in order to improve the agents' performances due to low hygiene factors and insufficient of motivating factors. Furthermore, the Kendall coefficient of concordance W obtained mostly high and highly significant. It could be concluded that AEA performed best in respectively involving informal leaders, farmer group development, extension work plan, using extension method, program planning; and performed well in evaluation and reporting subject matters development, farmer self reliance development, office maintenance and administrative, rural economic development and need assessment. Finally, Agriculture extension agent performed unsatisfactorily in evaluation and reporting, networking and professional development.
\end{abstract}

Keyword: agricultural extension agent, job performance, motivator factors, hygiene factors

\section{PENDAHULUAN}

Kinerja merupakan terjemahan dari bahasa Inggris, work performance atau job performance tetapi dalam bahasa Inggrisnya sering disingkat menjadi performance saja. Kinerja dalam bahasa Indonesia disebut juga prestasi kerja. Kinerja atau prestasi kerja (performance) diartikan sebagai ungkapan kemampuan yang didasari oleh pengetahuan, sikap, keterampilan, dan motivasi dalam menghasilkan sesuatu. Masalah kinerja selalu mendapat perhatian dalam manajemen karena sangat berkaitan dengan produktivitas lembaga atau organisasi.

\footnotetext{
${ }^{*}$ Korespondensi Penulis. Telepon: 08128214858

E-Mail: sufi149@yahoo.com
}

Menurut Robbins (1996) kinerja merupakan fungsi interaksi antara kemampuan atau ability (A), motivasi atau motivation (M) dan kesempatan atau Opportunity (O), yaitu Kinerja $=f(\mathrm{~A} \times \mathrm{M} \times \mathrm{O})$. Hal ini berarti kemampuan dan kemauan atau dorongan dan semangat kerja seseorang bisa jadi dihadapkan pada rintangan yang menghambat optimalisasi perwujudan kinerja seseorang. Dengan demikian, kinerja pada dasarnya ditentukan oleh tiga hal, yaitu: (1) kemampuan, (2) keinginan dan (3) lingkungan.

Oleh karena itu, agar mempunyai kinerja yang baik, seseorang harus mempunyai keinginan yang tinggi (motivasi) untuk mengerjakan serta mengetahui pekerjaannya dan apa yang diharapkan dalam upaya mencapai tujuan suatu organisasi secara legal, 
Jurnal Penyuluhan, Maret 2009 Vol. 5 No. 1

tidak melanggar hukum dan tidak bertentangan dengan moral atau etika (Donnelly et al. dalam Veithzal dan Ahmad Fawzi, 2005). Menurut Winardi (2001), perilaku (behaviour) pada dasarnya berorientasi terhadap tujuan, artinya perilaku pada umumnya dimotivasi oleh keinginan untuk mencapai suatu tujuan. Tujuan yang sebenarnya seringkali tidak disadari oleh setiap orang.

Jika kebutuhan terkuat dari seseorang sudah diketahui, maka untuk mempengaruhi perilaku dalam organisasi perlu ditetapkan tujuan yang tepat untuk menciptakan lingkungan kerja sehingga menjadi sumber motivasi bagi seseorang untuk bekerja. Demikian juga, jika kita mengetahui tujuan yang ingin dicapai untuk kepuasannya, maka kita dapat memprediksi apa kebutuhan yang paling kuat dari dirinya. Hal ini memungkinkan karena sudah terbukti bahwa uang dan keuntungan cenderung memuaskan tingkat kebutuhan fisiologis dan keamanan; hubungan interpersonal dan supervisi sebagai contoh dari faktor hygiene cenderung memuaskan tingkat kebutuhan sosial; peningkatan tanggung jawab, tantangan pekerjaan, serta kesempatan untuk berkembang sebagai faktor motivator cenderung memberikan kepuasan pada tingkat kebutuhan penghargaan dan aktualisasi diri. Karena itu, permasalahan penelitian ini adalah: (1) Bagaimana faktor-faktor motivator sebagai penumbuh dan pemicu munculnya keinginan penyuluh pertanian untuk bekerja dengan baik? (2) Bagaimana faktor-faktor hygiene yang memelihara perasaan tidak puas penyuluh pertanian terhadap kondisi kerja? dan (3) Bagaimana faktor-faktor motivatorhygiene hubungannya dengan kinerja penyuluh pertanian? Berdasarkan masalah penelitian tersebut maka secara rinci tujuan penelitian adalah sebagai berikut: (1) Mengidentifikasi deskripsi faktor-faktor motivator penyuluh pertanian di Jawa Barat, (2) Mengidentifikasi deskripsi faktor-faktor hygiene penyuluh pertanian di Jawa Barat, dan (3) Mengukur keeratan hubungan antara faktor-faktor motivator-hygiene dengan kinerja penyuluh pertanian di Jawa Barat.

\section{METODE PENELITIAN}

Penelitian dilaksanakan pada bulan Agustus 2007 sd. Desember 2007 di 17 kabupaten di Jawa Barat yaitu Cirebon, Kuningan, Indramayu, Majalengka, Garut, Tasikmalaya, Ciamis, Bandung Barat, Bandung, Sumedang, Cianjur, Karawang, Purwakarta, Bekasi, Subang, Cianjur dan Sukabumi. Populasi penelitian ini adalah penyuluh pertanian pegawai negeri sipil (PNS) yang mempunyai wilayah binaan di Jawa Barat. Jumlah populasi adalah 2562 orang penyuluh pertanian sedangkan jumlah sampel sebanyak 260 orang. Penarikan sampel menggunakan teknik stratified random sampling with proportional. Data karakteristik penyuluh dianalisis dengan menggunakan statistik descriptive analisis frequensi untuk mengetahui sebaran pada kategori variabel tertentu. Sedangkan untuk mendapatkan tingkat kesepakatan hubungan antara karakteristik dengan kinerja digunakan analisis konkordansi Kendall $W$ dan Kendal tau-b (Siegel, 1994; Siegel \& castellan, 1984). Reliabilitas diperoleh dengan Alpha Cronbach yaitu 0.81 sedangkan uji validitas dilakukan oleh pakar-pakar penyuluhan.

\section{HASIL DAN PEMBAHASAN}

\section{Faktor-Faktor Motivator dan Hygiene Penyuluh Pertanian di Jawa Barat}

Hasil penelitian terhadap persepsi penyuluh pada sejumlah faktor motivator-hygiene dapat dilihat pada Tabel 1 .

Tabel 1 menunjukkan hasil penelitian sebagai berikut (1) motivasi berprestasi sebagian besar penyuluh rendah, (2) persepsi penyuluh pada kesempatan pengembangan karir mereka cukup baik, (3) mayoritas tingkat kewenangan dan tanggungjawab penyuluh pertanian di Jawa Barat adalah tinggi, (4) persepsi penyuluh terhadap makna pekerjaan tinggi, (5) mayoritas penyuluh menilai insentif mereka rendah, (6) sistem administrasi dan kebijakan dinilai baik,(7) pembinaan dan supervisi masih kurang dan (8)kondisi kerja kurang. 
Tabel 1. Sebaran Penyuluh Pertanian Jawa Barat menurut persepsi mereka pada Sejumlah faktor Motivator dan Faktor Hygiene.

\begin{tabular}{lllllll}
\hline Peubah (X) & \multicolumn{9}{c}{ Kategori } \\
\cline { 2 - 7 } & \multicolumn{2}{c}{ Rendah } & \multicolumn{3}{c}{ Sedang } & \multicolumn{3}{c}{ Tinggi } \\
\cline { 2 - 7 } & Jumlah & $\%$ & Jumlah & $\%$ & Jumlah & $\%$ \\
& (orang) & & (orang) & & (orang) \\
\hline Motivasi berprestasi & 83 & 31.9 & 98 & 37.7 & 79 & 30.4 \\
Kesempatan pengembangan karir & 56 & 21.5 & 144 & 55.4 & 60 & 23.1 \\
Tingkat Kewenangan-tanggungjawab & 44 & 16.9 & 103 & 39.6 & 113 & 43.5 \\
Makna Pekerjaan & 79 & 30.4 & 70 & 26.9 & 111 & 42.7 \\
Honor dan Gaji & 136 & 52.3 & 72 & 27.7 & 52 & 20 \\
Sistem administrasi\&kebijakan & 36 & 13.8 & 113 & 43.5 & 111 & 42.7 \\
Pembinaan dan supervisi & 125 & 48.1 & 53 & 20.4 & 82 & 31.5 \\
Kondisi kerja & 99 & 38.1 & 85 & 32.7 & 76 & 29.2 \\
\hline
\end{tabular}

Nilai rendah untuk motivasi berprestasi penyuluh menunjukkan masih kurangnya faktor pendorong bagi penyuluh dalam bekerja dan menunjukkan kurangnya kepuasan kerja yang menurut Herzberg dalam Hersey dan Blanchard (1977:66)berakibat pada kurangnya peningkatan kinerja. Menurut teori motivasi McClelland, mereka yang memiliki motivasi berprestasi tinggi adalah mereka yang memiliki dorongan untuk mencapai sukses, daripada sekedar mendapatkan penghargaan. Sementara Maslow dengan teori piramida kebutuhan menyatakan bahwa kebutuhan penghargaan akan tertunda jika kebutuhan dasar manusia belum terpenuhi yaitu kebutuhan fisiologis dan keamanan. Maka rendahnya motivasi berprestasi dari sebagian besar penyuluh boleh jadi disebabkan oleh belum terpenuhinya kebutuhan dasar tersebut hal ini terbukti dengan rendahnya insentif, pembinaan dan supervisi serta rendahnya kondisi kerja.

Kesempatan promosi dan harapan pengembangan karir penyuluh sebagian besar berada pada kategori sedang. Penyuluh sebagai jabatan fungsional mempunyai peluang promosi lebih cepat dibandingkan dengan mereka yang non penyuluh, namun dalam kenyataannya kesempatan promosi tersebut tidak mudah diraih bagi sebagian besar penyuluh, karena keterbatasan kemampuan dalam melaksanakan tugas atau karena beban pekerjaan diluar tugas pokok dan fungsi (TUPOKSI) mereka. Hal ini terungkap dalam wawancara dengan para penyuluh di Jawa Barat bagian Timur.Tingkat kewenangan dan tanggung jawab penyuluh dalam melaksanakan penyuluhan berada pada kategori tinggi. Hal ini mengandung arti bahwa sebagian besar penyuluh memiliki kewenangan dan tanggungjawab yang tinggi dalam pengambilan keputusan mengenai apa dan bagaimana pelaksanaan penyuluhan di wilayah binaannya.

Sementara itu, lebih dari setengahnya jumlah responden penyuluh pertanian di JawaBarat ( $52.3 \%$ ) berpendapat bahwa Gaji dan Honor mereka rendah. Namun demikian Gaji dan Honor yang rendah menurut penilaian sebagian besar penyuluh pertanian tersangat nyata bukan satu-satunya faktor yang membuat semangat kerja mereka menurun. Persangat nyataan ini disampaikan oleh beberapa orang penyuluh yang mesangat nyatakan bahwa meskipun gaji/honor penyuluh tidak memadai mereka tetap semangat bekerja. Hal ini sesuai dengan pendapat Vroom yang dikutip Sadighi (2006:603) bahwa jika mereka percaya bahwa mereka bekerja untuk suatu hal yang bernilai, dihargai, maka mereka akan bekerja lebih giat. Namun demikian bukan berarti bahwa jika gaji atau honor penyuluh diabaikan akan tetap terpelihara semangat kerja. Sadighi (2006:603) mengemukakan bahwa penyuluh akan mendapat kesulitan dalam melayani kliennya jika tidak diberi Gaji dan Honor yang memadai.

Sistem administrasi dan kebijakan penyuluhan pada saat penelitian dilakukan disangat nyatakan bernilai sedang oleh sebagian besar penyuluh (43.5\%). Hal ini menunjukkan bahwa penyuluh belum puas dengan manajemen organisasi kerja maupun kebijakan dan prosedur kerja, namun 
Jurnal Penyuluhan, Maret 2009 Vol. 5 No. 1

mempunyai harapan yang lebih baik dimasa yang akan datang.

Perbedaan kelembagaan penyuluhan di tingkat kabupaten berimplikasi pada perbedaan sistem administrasi dan kebijakan. Sistem administrasi dan kebijakan dinilai sedang saat penelitian sebagai akibat dari adanya harapan penyuluh dalam perbaikan sistem setelah diberlakukannya undang-undang penyuluhan.

Pembinaan dan supervisi masih berada pada kategori rendah menurut sebagian besar responden ( 48.1\%). Berdasarkan hasil wawancara dengan penyuluh pertanian ahli di Kabupaten Bogor diketahui bahwa anggaran untuk pembinaan dan supervisi penyuluh pada tahun 2007 dihapuskan, sehingga penyuluh mendapatkan kesulitan untuk melakukan pembinaan dan supervisi kepada penyuluh di lapangan.

Kondisi kerja dinilai rendah oleh sebagian besar penyuluh, artinya sarana prasarana dan perlengkapan kerja penyuluh tidak memadai. Kondisi kerja ini juga memberikan gambaran buruknya dukungan institusi penyuluhan terhadap pelaksanaan tugas penyuluh.

Secara keseluruhan dapat dinyatakan bahwa faktor-faktor motivator penyuluh pertanian berada pada kondisi tidak rendah, artinya faktor-faktor yang dapat menumbuhkan kepuasan kerja masih cukup memadai meskipun tidak tinggi. Sedangkan faktorfaktor hygiene yaitu faktor yang mencegah munculnya ketidakpuasan kerja berada pada kategori rendah. Ilustrasi faktor-faktor motivator dan faktor-faktor hygiene penyuluh pertanian di Jawa Barat dapat digambarkan sebagai roket motivasi pada Gambar 1 .

Gambar 1 menunjukkan bahwa keberadaan faktor-faktor motivator yang terdiri dari motivasi berprestasi, kesempatan pengembangan karir, kewenangan dan tanggung jawab serta pemaknaan terhadap pekerjaan dan faktor-faktor hygiene yang terdiri dari gaji dan honor, administrasi dan kebijakan, pembinaan dan supervisi serta kondisi kerja dapat digambarkan sebagai roket dan landasan pacunya.

Faktor-faktor motivator digambarkan sebagai roket sedangkan faktor-faktor hygiene merupakan landasan pacu bagi faktor motivator untuk meluncur. Kondisi faktor hygiene yang rendah pada penyuluh pertanian di Jawa Barat dapat menyebabkan roket motivator tidak memiliki 'flatform' pada landasannya, sehingga tidak dapat menghasilkan pencapaian
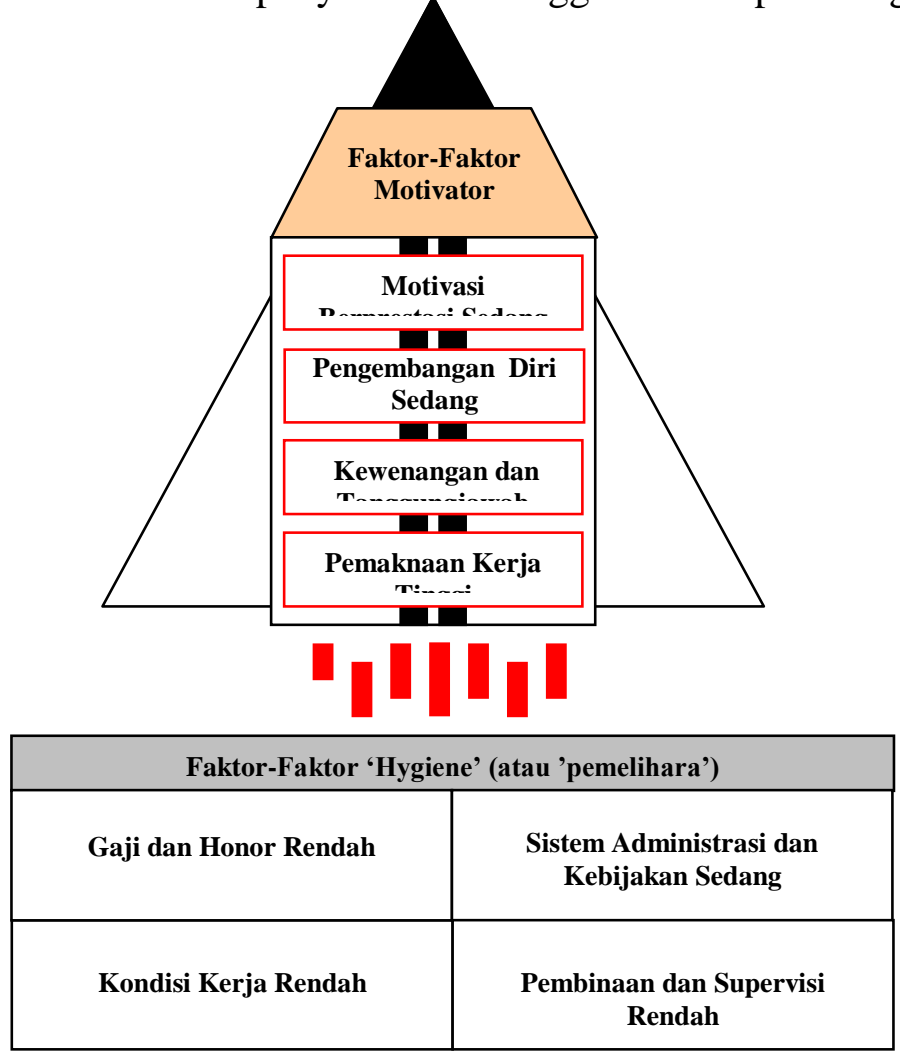

Gambar 1 Faktor-faktor motivator-hygiene penyuluh pertanian Jawa Barat 
Jurnal Penyuluhan, Maret 2009 Vol. 5 No. 1

kinerja yang sesuai dengan harapan. Faktorfaktor hygiene tidaklah menimbulkan kepuasan kerja maupun produktifitas kerja, namun jika tidak memadai maka yang muncul adalah ketidak puasan kerja, itulah sebabnya disebut sebagai faktor hygiene yaitu faktorfaktor yang akan memelihara kesehatan lingkungan kerja, karena terhindar dari ketidakpuasan kerja.

\section{Hubungan Faktor-Faktor Motivator dan Hygiene Dengan Kinerja Penyuluh Pertanian Di Jawa Barat}

Hasil analisis koefisien konkordansi Kendal W dan Kendal tau_b pada Tabel 2 menunjukkan peubah motivator-hygiene yang berhubungan dengan kinerja penyuluh pertanian. yang memiliki dorongan yang kuat untuk berprestasi lebih mengutamakan bidang kerja penumbuhkembangan kelompok tani yaitu mendorong penumbuhan kelompok, mendorong penumbuhan asosiasi kelompok mendorong penumbuhan dinamika kelompok mendorong peningkatan kemampuan kelompok. Kebutuhan akan penghargaan akan terpenuhi jika seseorang berprestasi (Ivanchevic, 2005), dengan penumbuhan kelompok maka penyuluh akan mendapatkan penghargaan berupa imbalan atau pujian.

Kesempatan pengembangan karir merupakan salah satu bentuk penghargaan bagi mereka yang berprestasi, terbukti berhubungan sangat nyata dengan kinerja (W $\left.=0.98^{* *}\right)$. Penyuluh yang memiliki kesempatan pengembangan karir tinggi mengutamakan penumbuhan kelompok. Seorang pekerja akan merasakan kebutuhan hidup yang

Tabel 2. Hubungan motivator-hygiene penyuluh dengan Kinerja Penyuluh Pertanian

\begin{tabular}{lcl}
\hline Motivasi berprestasi & W & $=0.96^{* *}$ \\
Kesempatan pengembangan karir & $\mathrm{W}$ & $=0.98^{* *}$ \\
Tingkat kewenangan dan tanggungjawab & $\mathrm{W}$ & $=0.97^{* *}$ \\
Makna pekerjaan & $\mathrm{W}$ & $=0.96^{* *}$ \\
Gaji dan Honor & $\mathrm{W}$ & $=0.97^{* *}$ \\
Sistem administrasi dan kebijakan & $\mathrm{W}$ & $=0.90^{* *}$ \\
Pembinaan dan supervisi & $\mathrm{W}$ & $=0.97^{* *}$ \\
Kondisi kerja & $\mathrm{W}$ & $=0.98^{* *}$ \\
\hline
\end{tabular}

Hasil analisis konkordansi Kendall W pada Tabel 2 menunjukkan bahwa Motivasi berprestasi, kesempatan pengembangan karir, tingkat kewenangan dan tanggungjawab, makna pekerjaan, Gaji dan Honor, pembinaan dan supervisi serta kondisi kerja memiliki hubungan signifikan dengan kinerja penyuluh pertanian. Hal ini berarti bahwa baik atau buruknya kinerja penyuluh pertanian sangat erat kaitannya dengan baik buruknya faktorfaktor motivator dan faktor-faktor hygiene di tempat kerja penyuluh pertanian.

Motivasi berprestasi berkorelasi sangat nyata dengan kinerja $\left(\mathrm{W}=0.96^{* *}\right)$. Penyuluh tidak terpenuhi. Dan kondisi tersebut akan berlangsung pada seorang pekerja pada saat tertentu. Kekurangan akan kebutuhan tersebut dapat menjadi energi atau pemicu bagi seseorang untuk berprilaku (Hersey dan Blanchard, 1977).

Kewenangan dan tanggungjawab penyuluh sangat nyata berhubungan ( $\mathrm{W}=$ 0.97**) dengan kinerja penyuluh. Penyuluh yang memiliki kewenangan dan tanggungjawab yang tinggi sangat baik dalam melaksanakan bidang kinerja penyusunan rencana kerja penyuluhan. Hal ini membuktikan bahwa penyusunan rencana kerja yang 
Jurnal Penyuluhan, Maret 2009 Vol. 5 No. 1

terdiri dari bukti adanya susunan rencana kerja tahunan, jadwal kegiatan mingguan, penetapan hasil /outcome yang diharapkan dari setiap kegiatan, penetapan kolaborasi penggunaan sumberdaya/sarana dengan pihak terkait merupakan indikasi tingkat tanggungjawab dan kewenangan penyuluh terhadap pelaksanaan pekerjaannya. Menurut Van den Ban dan Hawkins (1999: 314) peranan penyuluh pertanian adalah membantu petani membentuk pendapat yang sehat dan membuat keputusan yang baik dengan cara berkomunikasi dan memberikan informasi yang diperlukan. Maka tanggung jawab penyuluh adalah mempromosikan dan melengkapi proses belajar petani dengan memperhatikan sistem nilai mereka.

Hubungan makna pekerjaan bagi penyuluh dengan kinerja adalah sangat nyata (W=0.96**). Penyuluh yang menilai tinggi terhadap makna pekerjaannya yaitu mereka yang menganggap bahwa pekerjaan sebagai penyuluh adalah pekerjaan yang tidak membosankan karena membutuhkan banyak keterampilan dan keahlian (Variasi tugas), hal ini sesuai dengan Dubin dan Goldman (1972) yang mengemukakan bahwa pekerjaan yang membutuhkan lebih banyak keahlian yang menantang dan lebih beragam menempati kepentingan atau kebutuhan hidup yang lebih sentral bagi individu daripada pekerjaan yang tuntutan keahliannya rendah dan bersifat rutin. Kepentingan atau semangat kerja yang nampak secara psikologis dalam penelitian tersebut menggambarkan bahwa orang tersebut terus bekerja seolah-olah bukan karena pertimbangan ekonomi saja melainkan pertimbangan nonekonomi juga.

Selain itu penyuluh yang memiliki penilaian tinggi terhadap makna pekerjaan menganggap pekerjaan penyuluhan banyak memberi manfaat terhadap orang banyak ( signifikansi tugas), dan bahwa pekerjaan penyuluhan memiliki kejelasan dari awal hingga hasilnya. Penyuluh yang memiliki penilaian tinggi terhadap makna pekerjaan lebih mengutamakan pelibatan masyarakat, hal ini terjadi karena dengan pelibatan masyarakat maka nilai signifikansi tugas semakin tinggi.
Administrasi dan kebijakan berhubungan sangat nyata dengan kinerja ( $\mathrm{W}=0.90 * *)$. Demikian juga pembinaan dan supervisi sangat nyata hubungannya dengan kinerja $(\mathrm{W}=$ 0.97**). Administrasi dan kebijakan serta pembinaan dan supervisi erat kaitannya dengan tipe kelembagaan penyuluhan di masing-masing tempat kerja penyuluh. Pada kelembagaan kantor penyuluhan yang memiliki anggaran operasional sendiri lebih memungkinkan untuk melaksanakan pembinaan dan supervisi dengan baik demikian juga administrasi dan kebijakan lebih baik kondusif daripada kelembagaan non kantor penyuluhan.

Kondisi kerja berhubungan sangat nyata dengan kinerja ( $\left.\mathrm{W}=0.98^{* *}\right)$. Kondisi fisik lingkungan kerja penyuluh masih rendah, hal ini terjadi karena akses terhadap sarana prasarana kerja seperti akses terhadap sumbersumber informasi, akses terhadap sarana pendukung kerja masih rendah, demikian juga penghargaan dan pengakuan terhadap penyuluh belum memadai.

\section{KESIMPULAN}

1. Faktor-faktor motivator pendorong semangat kerja tidak memadai yaitu motif berprestasi rendah, kesempatan pengembangan karir dan promosi rendah.

2. Penyuluh pertanian bekerja dengan faktorfaktor hygiene pencegah ketidakpuasan kerja rendah yaitu kondisi kerja (saranaprasarana pendukung kerja) kurang baik, gaji dan honor rendah dan supervisi/ pembinaan kurang.

3. Faktor-faktor motivator yang terdiri dari motivasi berprestasi, kesempatan pengembagan karir, kewenangan dan tanggung jawab serta makna pekerjaan berhubungan sangat nyata dengan kinerja, demikian juga faktor-faktor hygiene yang terdiri dari Gaji dan honor, administrasi dan kebijakan, pembinaan dan supervisi dan kondisi kerja. 
Jurnal Penyuluhan, Maret 2009 Vol. 5 No. 1

\section{DAFTAR PUSTAKA}

Dubin, R.S. dan Goldman, D.R. 1972. Central life interest of American Middle Manager and Specialists. Journal of Vocasional Behavior, 2.

Hackman, J.R. 1980. Work Redesign: Reading Massachussets. Addison-Wesley

Hersey, P. dan Blanchard K. H. 1977. Management of organizational Behavior: Utilizing Human Resources. New Jersey: Prentice Hall, Inc, Englewood Cliffs.

Herzberg, Frederick. (2006). One more time: how do you motivate employees? Harvard Business Review Classic, January-February 1968. http://aplnrichmond.pbwiki.com/f/HerzbergArticle. $p d f$ [23 Januari 2007]

http://www.aiaee.org/2006/Accepted/600.pdf [ 19 Januari 2007]

Sadighi, Hassan. 2006. Factors affecting agricultural extension personnel's motivation level. Proceedings of the $22^{\text {nd }}$ Annual Conference.

Schemerhorn, J. R., Hunt,J.G., Osborn,R.N.1991. Managing Organizational Behavior. Canada. John Willey \& Sons, Inc.

Schultz, D.P., Schultz, S.E. 1994. Psychology And Work Today: An Introduction To Industrial And Organizational Psychology. New York: MacMillan Publishing Company. $5^{\text {th }}$ Edition.

Siegel, S. dan Castellan. N.J. 1988. Nonparametric Statistics for the behavioral sciences. Singapore: McGraw-Hill Book Co.p. 245-280.

Siegel, S. 1999. Statistik nonparametric untuk ilmu-ilmu sosial. Jakarta: Gramedia

Van den Ban, A.W., Hawkins, H.S. 1999. Penyuluhan Pertanian. Yogyakarta: Kanisius.

Veithzal R., A.F.M. Basri. 2005. Performance Appraisal. Jakarta: PT Raja Grafindo Persada

Werther, W.B.JR., Davis, K. 1989. Human Resources and Personnel Management. 3th Ed. USA: McGraw-Hill, Inc. 